\title{
The Motives Behind Transport Mode Choice: a Study with University Students in Brazil
}

\author{
Alexandre Gori Maia \\ Cristiane Silva de Carvalho \\ Leonardo César Venâncio \\ Eduardo Dias Dini
}

${ }^{I}$ University of Campinas, Institute of Economics, Campinas, São Paulo, Brazil.

II Centro Regional Fundación CEQUA, Punta Arenas, Región de Magallanes y la Antártica Chilena, Chile.

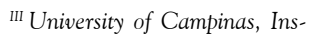
titute

of Economics, Campinas, São Paulo, Brazil.

${ }^{\text {IV }}$ Centro Regional Fundación CEQUA, Punta Arenas, Región de Magallanes y la Antártica Chilena, Chile.

\begin{abstract}
We analyze the main reasons for the transport mode choice (private vehicle, public transportation, bicycle, walking, and others) among university students in Campinas. Analyses are based on primary data collected from 1,179 students through online and personal interviews in the second semester of 2014. Multiple Correspondence Analysis and Cluster Analysis are jointly used to identify common choice groups. Public transport prevails among low-income users, and the main motive for their choice is the lack of alternatives. Students who can afford higher costs tend to prefer a private vehicle, which is seen as being safer and more comfortable. In turn, the adoption of an active mode of transport remains mainly restricted to a small group of users with positive attitudes towards health and the environment. The study finally discusses the implications of structural constraints, such as infrastructure and public safety, on public policies aimed at a sustainable urban transport system.
\end{abstract}

Keywords: Active transport; bicycle; urban public transport; walking; multivariate analysis;

São Paulo. Vol. 23, 2020

Original Article

DOI: http://dx.doi.org/10.1590/1809-4422asoc20170188r4vu2020L5AO 


\section{Introduction}

The transport sector in Brazil takes second place in the emissions of greenhouse gases (GHG), (MCTI, 2014). For decades, the main metropolitan cities have struggled with traffic congestion, air and noise pollution (DE VASCONCELLOS, 2005). In Campinas, which has one of the highest populations and average commuting time in Brazil (STM, 2012), the total number of registered vehicles has increased by $47 \%$ in the last 10 years (DENATRAN, 2015). The motorization rate exceeds that of most developed countries (UNECE, 2015): almost 700 thousand private cars and more than 100 thousand motorcycles for a population of 1 million inhabitants.

Despite recent efforts to promote policies of sustainable urban accessibility, the use of private modes of transport in Brazilian megacities is still high when compared to other developing nations (IEA, 2008). The benefits of a wider adoption of public and active modes of transport would be several. Policies to stimulate the use of public transportation have highlighted their potential to reduce congestions and GHG emissions, although these benefits may be partially undermined by under-utilization of transit capacity and the source of energy (BEAUDOIN; FARZIN; LIN LAWELL, 2015; KENNEDY, 2002; MENEZES; MAIA; DE CARVALHO, 2017). Users of public transport also tend to have more walking time and daily overall physical activity than non-users (MULLEY et al., 2016; SAELENS et al., 2014), although the magnitude of the benefits on health is still uncertain (SENER; LEE; ELGART, 2016). Policies to increase the use of active transport tend to generate broader health benefits, through increased physical activity (DE NAZELLE et al., 2011), reduced levels of cholesterol and obesity (PUCHER et al., 2010; SCHAUDER; FOLEY, 2015), reduced prevalence of common diseases, such as diabetes and heart disease (JARRETT et al., 2012), and overall beneficial impacts on all-cause mortality and on life expectancy (ROJAS-RUEDA et al., 2012). Reduced commuting time and traffic accidents through public and active transportation can also have positive impacts on economic growth (UNEP, 2011).

Although the potential benefits of public and active transport are well documented, the success of policies of sustainable urban transport depends crucially on understanding the general motives of individuals' choices (BÖSEHANS; WALKER, 2016). For example, rising car ownership has been highlighted as a key factor to explain downward trends in the use of public transport (BRESSON et al., 2004). Income growth is expected to increase the number of trips and their average length. But it also increases car ownership and, thus, it will have a secondary and negative impact on the demand for public transport via car ownership (PAULLEY et al., 2006). In populations with a large supply of cars, even strong action to improve public transport may not be enough in itself to increase its adoption (BONNEL; CHAUSSE, 2000).

The choice of the mode of transport is also influenced by factors such as individual characteristics, lifestyle and, above all, the perception of the services' quality (BEIRÃO; SARSFIELD CABRAL, 2007). In this sense, public transport would attract private car users by improving the quality of its services, although these improvements will also depend chiefly on the motivations behind the use of private vehicles (REDMAN et 
al., 2013). Private cars are generally perceived as more comfortable, flexible, faster in keeping up with modern lifestyles, and also generating affective and symbolic feelings of status, autonomy and safety (BERGSTAD et al., 2011; ESPINO; DE DIOS ORTÚZAR; ROMÁN, 2007; LOIS; LÓPEZ-SÁEZ, 2009). In fact, subjective feelings of safety have shown themselves to be an important factor affecting users' choice of a car mode and encouraging them to shift to public transport (JAIN et al., 2014; KAMARGIANNI et al., 2015; ŞIMŞEKOĞLU; NORDFJÆRN; RUNDMO, 2015).

Another important motive affecting the choice for public transport is the time spent in assessing bus service and in reaching final destination (walk time), time waiting at the bus stop (waiting time), fare, time spent in the vehicle or at an interchange (in-vehicle time, IVT), and accessibility for as many people as possible (POLAT, 2012). Travel time, which includes walking time, waiting time and IVT, depends crucially on the spatial distribution of the bus stops, the frequency of the buses and the provision of accurate information on bus schedules. Increases in the distance of the bus stops from home or destination, which determines the availability of the public transport, tend to decrease the use of public transport (KRYGSMAN; DIJST; ARENTZE, 2004). In turn, the provision of information can potentially reduce the uncertainty associated with public transport trips and improve the overall level of service (CATS; LOUTOS, 2016).

Studies in developed countries show that walking and cycling are alternative modes of transport for those travelling short distances, especially for younger and more educated people, but their adoption will depend largely on the provision of a proper infrastructure, such as built environment, segregated bicycle lanes or a rental system (RUIZ; BERNABÉ, 2014; WOODS; NELSON, 2014). Weather conditions, such as high levels of rainfall and extreme temperatures, also tend to reduce the adoption of active transport (PARKIN; WARDMAN; PAGE, 2008). The physical conditions and attitudes toward health and environment are also important, as well as the perception of safety (GATERSLEBEN; APPLETON, 2007). Most users may also decide not choose an active mode of transport if the crime rate in their neighborhood is high, even though the built environment is walkfriendly (YANG, 2016). Improving the residents' perception of the cycling environment may also help, for example, through better information about bicycle routes and regular public cycling activities to familiarize residents with the bike-friendly designs within their neighborhood (MA; DILL, 2015).

We analyze the main motives related to the adoption of the modes of transport among university students in Campinas. Specifically, we investigate how personal and travel characteristics (e.g., gender, income, health status, and travel time), perceptions and attitudes (associated with cost, time, comfort, health, environment, safety and lifestyle) are related to the choices for the mode of transport (private vehicle, public transportation, bicycle, walking, and others). In order to discuss strategies to stimulate the use of public transport, we also investigate how users perceive the quality of its system in the city.

Analyses are based on primary data collected from 1,179 students through online and personal interviews. Multivariate statistical analyses are used to identify the relationships among the multiple nominal variables at the same time. Firstly, the Multiple 
Correspondence Analysis (MCA) identified few dimensions related to the patterns of association between the characteristics of analysis. Secondly, the Cluster Analysis (CA) grouped the characteristics with similar values for the dimensions of the MCA, defining common patterns of association with the mode of transport.

One main advantage of these multivariate analyses in comparison to more traditional regression analysis, such as discrete choice analyses used in the modelling of transportation systems (BEN-AKIVA; LERMAN, 1985), is that their estimation methods are not subjected to biases caused by endogeneity or sample self-selection. Transport mode and health status, for example, tend to be endogenous since these variables are jointly determined. Moreover, the MCA and CA allow us to identify and describe patterns and attitudes related to common groups of users, rather that the cause-effect relations between selected explanatory variables and transport mode.

\section{Material and Methods}

\section{Data source}

We applied an exploratory survey to undergraduate and graduate students in a university campus in Campinas. The population under analysis comprised more than 35 thousand students. The sample contained 1,179 respondents (nearly $3 \%$ of the population), including: 560 random selected personal interviews and 619 online interviews. Supposing a confidence level of $95 \%$, this total sample size guarantees a maximum margin of error of only 2.3 percentage points in our estimates (COCHRAN, 1977).

Both the personal and the online interviews were applied in the second semester of 2014, between August and November. The personal interviews were conducted in the most crowded localities of the university (such as the classroom buildings and university restaurants). The interviewers, who were undergraduate students, visited the sites on different weekdays, at different times in the morning, afternoon and evening. In turn, the calls to participate in the online survey were carried out through the university social networks. The list of social networks was obtained in the university departments. We avoided repeated answers by checking the university ID number of each interviewed.

Online interviews would imply some sources of sample selection bias, since unobserved characteristics would jointly affect the choice for the transport mode and the characteristics under analysis. Nonetheless, we show below that this is not a main concern in this study, since the choices for the modes of transport do not differ strongly between the two samples. Moreover, the multivariate analyses used in this study tend to be robust to this source of bias, since they only estimate the multiple correlation among the observed characteristics of analysis. In other words, they neither imply cause-effect relations nor make assumptions about the conditional distribution of the unobserved error, which is the main source of bias in the sample selection (WOOLDRIDGE, 2003, cap. 17).

The questionnaires contained students' characteristics and habits of transport and was based on the National Household Travel Survey (FDA, 2009). The question of central interest in the survey was the commuting mode from home to university (Table 
1): (1) walking, (2) private vehicle, (3) ride, (4) chartered bus, (5) intercampus shuttle, (6) public bus, (7) bicycle and (8) other.

We also asked questions about the characteristics of the users, commuting time, reasons for choosing the transport type and evaluation of the public transit in Campinas. The variables are presented in Tables 2, 3 and 4. The interviewees self-reported their health status in five categories: very good; good; regular; bad; and very bad. For analytical simplicity, these five categories were dichotomized into good health (very good or good) and bad health (regular, bad and very bad). We used similar procedures to dichotomize the evaluations of the characteristics of public transport in Campinas (very good, good, regular, bad, and very bad) into good and bad (Table 4).

\section{Multiple Correspondence Analysis}

We used MCA to reduce the information presented in the joint distribution of the multiple categories of analysis. This method determines the number of dimensions needed to better represent the structure of relationship among the nominal categories. MCA is based on the technique of principal components to simplify the structure of the data, identifying a few dimensions that can explain a large share of the information presented in the contingent data (GREENACRE, 2007).

The MCA represents the distances between the categories of analysis by the chisquared statistics, a measure of the differences between the relative frequencies of the matrix of cross tabulations (profiles). The inertia represents the degree of variation among the profiles. The higher the deviation of the relative frequencies from their expected (average) values, the higher the total inertia.

The MCA decomposes the structure of correlation of the matrix of distances in dimensions represented by: i) eigenvectors, which express the projection of these distances in a geometric space; ii) eigenvalues, which express the contribution of each dimension to explain the total inertia. After identifying the key dimensions that represent the variation in the data, MCA facilitates the understanding of the structure of associations between the categories.

The geometric dispersion of the categories in the geometric space defined by the dimensions of the MCA represents the patterns of associations between the qualitative variables (HOFFMAN; FRANKE, 1986). Groups of categories that are close together reveal similar patterns of association. Groups of categories that are further apart reveal repulsion between them. Categories that are near the origin of a dimension (centroid) have low contribution to its total inertia, i.e., their frequencies slightly differ in relation to the structure represented by the dimension.

\section{Cluster Analysis}

We applied CA to aggregate the categories of analysis with similar values for the dimensions of the MCA. CA is a multivariate hierarchical classification technique that distributes the observations among mutually exclusive groups, such that the characteris- 
tics are homogeneous within groups and heterogeneous between them (ANDERBERG, 1973; HARTIGAN, 1975). The clustering method adopted in this paper is that of Ward, which creates hierarchical groups such that the variances within groups are minimal and the variances between them are maximal. The criterion for this technique in each stage of aggregation is to find the next class that minimizes the variability within the new group. In order to better understand the contribution of the sum of squares within groups (within variability), this sum was divided by the total sum of squares (total variability) to represent a maximum proportion of the variability (semi-partial R2). In the first stage, there is zero degree of generalization (all observations are distinct from each other). By the end of the process, there is 100\% generalization (all observations are similar to each other). The ideal number of clusters is that which minimizes the analytical effort and presents a reasonable degree of generalization.

\section{Results}

Characteristics of the users

The main modes of transport in our sample were (Table 1): public bus (25\%), walking (24\%) and car (24\%). Next came bicycle (9\%), intercampus shuttle (8\%), ride (5\%) and chartered bus (5\%). This latter mode is used mainly by students living in other municipalities. The intercampus shuttle service is mainly used by students living in the "Moradia", multiple occupancy rooms near the university that are offered free of charge for students of low socioeconomic status.

The chi-square statistic tested the null hypotheses of equality between observed and expected frequencies. In other words, the statistic tested how different was the distribution of users among the modes of transport for the groups of personal and online interviews. In spite of a slight over-representation of chartered bus users in the personal interviews, and bicycle users in the online survey, there are no huge differences between the frequencies in the two sample designs. Thus, in order to simplify interpretations, without generating serious distortions in the analysis, the association standards between the characteristics of interest will be analyzed considering the aggregated sample of the 1,179 interviews. 
Table 1 - Sample number according to the mode of transport and type of interview (chi-square statistic between parentheses)

\begin{tabular}{|c|c|c|c|c|c|c|}
\hline \multirow{2}{*}{ Modal } & \multicolumn{2}{|c|}{ Personal } & \multicolumn{2}{|c|}{ Online } & \multicolumn{2}{|c|}{ Total } \\
\hline & $n$ & $\%$ & $n$ & $\%$ & $n$ & $\%$ \\
\hline Walking & 126 & 22.5 & 155 & 25.3 & 281 & 23.8 \\
\hline Private vehicle & 141 & 25.2 & 144 & 23.0 & 285 & 24.2 \\
\hline Ride & 30 & 5.4 & 28 & 4.4 & 58 & 4.9 \\
\hline Chartered bus & 40 & 7.1 & 18 & 2.9 & 58 & 4.9 \\
\hline Shuttle & 51 & 9.1 & 43 & 7.0 & 94 & 8.0 \\
\hline Bus & 135 & 24.1 & 157 & 25.2 & 292 & 24.8 \\
\hline Bicycle & 37 & 6.6 & 74 & 12.1 & 111 & 9.4 \\
\hline Total & 560 & 100.0 & 619 & 100.0 & 1,179 & 100.0 \\
\hline & & & & & & \\
\hline
\end{tabular}

Source: Research data.

*** Significant at $0.1 \% ; *$ Significant at $1 \% ; *$ Significant at $5 \% ;+$ Significant at $10 \%$.

The population under analysis represents a singular socioeconomic group (young people with a high level of education) and the choices for the modes of transport differ slightly from those of the whole population in Campinas. According to the survey "Origem e Destino" (Origin-Destination) carried out in 2011 (STM, 2012), the most frequent commutes in this city were done using own car or motorcycle $(32 \%$, against $24 \%$ in our sample), bus or shuttle (29\%, against $33 \%)$, walking (25\%, against $24 \%)$, ride (12\%, against $5 \%$ ) and bicycle (2\%, against $9 \%)$. The main differences are a slight overrepresentation of bicycles and underrepresentation of own vehicle in our sample, which may also be related to distance from origin to destination (which tend to be smaller in the university campus) and positive attitudes of young and well educated people toward environment and health.

Table 2 presents the percentage distribution and average values of selected characteristics according to mode of transport. All chi-square statistics are significant at $0.1 \%$, meaning that the characteristics are different among the modes of transport. Users of private vehicles prevail in higher income classes (53\% have household income equal to or higher than 8000 reais monthly), while users of public transportation or university shuttle prevail in the lower classes (respectively $27 \%$ and $43 \%$ of them with income up to 2400 reais monthly). Users of active transport (bicycle or walking) are associated with upper-middle class (34\% of those who walk or cycle have a household income between 4000 and 8000 thousand reais). The distance to the university is decidedly a key factor for the adoption of this mode of transport, as well as in the determination of the residential rents in this neighborhood. As a result, the university neighborhood tends to concentrate those students with middle and high income, who are more likely to commute in active transport. 
Table 2 - Percentage distribution (column \%) by mode of transport (chi-square statistic between parentheses)

Walking $\begin{gathered}\text { Private } \\ \text { Vehicle }\end{gathered}$ Ride $\begin{gathered}\text { Chartered } \\ \text { bus }\end{gathered} \quad$ Shuttle Bus Bicycle

Family Income

Up to 1,600

1,600 to 2,400

2,400 to 4,000

4,000 to 8,000

More than 8,000

\begin{tabular}{|rr|r|r|r|r|r|}
7.0 & 1.5 & 5.5 & 3.6 & 21.6 & 7.7 & 8.5 \\
\hline 9.7 & 3.4 & 10.9 & 12.5 & 21.6 & 19.5 & 10.4 \\
\cline { 2 - 7 } 19.0 & 11.9 & 23.6 & 19.6 & 30.7 & 33.8 & 22.6 \\
\hline 34.1 & 30.6 & 40.0 & 41.1 & 17.0 & 22.4 & 34.0 \\
\hline 30.2 & 52.6 & 20.0 & 23.2 & 9.1 & 16.5 & 24.5 \\
\hline \multicolumn{6}{|c|}{$(220.9)^{* * *}$}
\end{tabular}

Period
Morning
Evening

\begin{tabular}{|c|c|c|c|c|c|}
\hline 15.5 & 14.5 & 28.6 & 22.7 & 21.3 & 17.0 \\
\hline 78.0 & 85.5 & 71.4 & 77.3 & 78.7 & 83.0 \\
\hline
\end{tabular}

Sex

Man

Woman

\begin{tabular}{|c|c|c|c|c|c|}
\hline 47.8 & 47.3 & 53.6 & 46.6 & 46.3 & 61.3 \\
\hline 52.2 & 52.7 & 46.4 & 53.4 & 53.7 & 38.7 \\
\hline
\end{tabular}

Economic status

Non-employed

Employed

\begin{tabular}{|c|c|c|c|c|c|}
\hline 53.7 & 72.7 & 85.7 & 70.5 & 69.5 & 66.0 \\
\hline 46.3 & 27.3 & 14.3 & 29.5 & 30.5 & 34.0 \\
\hline
\end{tabular}

Health status

Very good, good

Regular, bad, very bad

\begin{tabular}{|cr|r|r|r|r|r|}
82.2 & 86.9 & 90.9 & 82.1 & 73.9 & 76.5 & 92.5 \\
\hline \multicolumn{7}{c|}{$(25.0) * * *$}
\end{tabular}

Travel time

Up to $10 \mathrm{~min}$

$\begin{array}{lll}44.4 & 38.9 & 30.9\end{array}$

$7.3 \quad 52.9$

1.9

65.1

10 to $20 \mathrm{~min}$

47.9

$32.1 \quad 36.4$

5.5

41.4

9.1

31.1

20 to $40 \mathrm{~min}$

7.8

23.8

21.8

20.0

4.6

22.3

3.8

More than $40 \mathrm{~min}$

$\begin{array}{ll}5.3 & 10.9\end{array}$

67.3

1.1

66.8

0.0

$$
(74.1)^{* * *}
$$

Source: Research data. *** Significant at $0.1 \% ; * *$ Significant at $1 \%$. 
The choice of active transport and rides is less frequent among students studying at night (15\% and 17\%, respectively), although the differences between the periods are not significant. Similarly, women are slightly underrepresented among the bicycle users (19\%), although the gender differences are also not significant.

The use of a private vehicle is significantly higher among students who are employed ( $46 \%$ of the users of private vehicle are employed), since they tend to require greater flexibility and speed in their commutes. In turn, the bicycle users tend to present the best self-reported health status ( $92 \%$ of them declared very good or good health), while the users of public transport are those with the worst evaluations (among the users of university shuttle and municipal buses, $26 \%$ and $23 \%$, respectively, declared regular, bad or very bad health status).

The active modes of transport are those with the shortest commute time, since these modes are primarily used for short distances and in neighborhoods offering exclusive bike lanes. More than $90 \%$ of those who walk or cycle spend up to 20 minutes in their commutes, while $67 \%$ of those who travel by public buses take more than 40 minutes to come to the university.

The reasons of the transport choice also differ significantly among the users' groups (Table 3). All chi-square statistics are significant at $0.1 \%$, meaning that the reasons are different among the modes of transport. Users of private vehicles highlight the commuting time (72\%) and comfort (57\%). Riders also mainly justify commuting time $(60 \%)$ and comfort (48\%). The users of the intercampus shuttle highlight the cost (71\%) and commuting time (50\%). In turn, the main motivations behind those who use public buses are the lack of options (70\%) and costs (52\%). This result is rather worrying, since it highlights the dissatisfaction of the population with the service offered by public transport.

The motivations of bicycle users are more diverse: time (66\%), cost (59\%), lifestyle (41\%), and health (40\%) are the most frequent. It is interesting to highlight that the environmental concerns have only a relatively high percentage among bicycle users (9\%), and safety only among the users of private vehicles (22\%). Moreover, although supporters of walking are associated with higher income classes (Table 1), the main reasons for their choices is the low cost (64\%), followed by the commuting time $(64 \%)$. 
Table 3 - Percentage of responses for the main reasons for choice according to the mode of transport (chi-square statistic between parentheses)

\begin{tabular}{|c|c|c|c|c|c|c|}
\hline Characteristic & Walk ing & $\begin{array}{l}\text { Private } \\
\text { Vehicle }\end{array}$ & Ride & $\begin{array}{l}\text { Charter ed } \\
\text { bus }\end{array}$ & Shuttle & Bus \\
\hline
\end{tabular}

Cost

\begin{tabular}{lll|r|r|r|r|r|} 
Yes & 63.7 & 19.3 & 36.2 & 65.5 & 71.3 & 52.1 & 58.6 \\
\hline No & 36.3 & 80.7 & 63.8 & 34.5 & 28.7 & 47.9 & 41.4 \\
\hline \multicolumn{6}{c|}{$(158,9)^{* * *}$}
\end{tabular}

Time

Yes

No

\begin{tabular}{|lr|r|r|r|r|r|}
50.9 & 72.3 & 60.3 & 31.0 & 50.0 & 7.2 & 65.8 \\
\hline 49.1 & 27.7 & 39.7 & 69.0 & 50.0 & 92.8 & 34.2 \\
\hline \multicolumn{7}{c|}{$(287.0) * * *$}
\end{tabular}

Health

Yes

\begin{tabular}{rr|r|r|r|r|r|}
21.7 & 3.9 & 6.9 & 1.7 & 2.1 & 0.3 & 40.5 \\
\hline 98.3 & 93.1 & 98.3 & 97.9 & 99.7 & 59.5 \\
\hline \multicolumn{7}{c|}{$(200.4) * * *$}
\end{tabular}

Environment

$$
\begin{aligned}
& \text { Yes } \\
& \text { No }
\end{aligned}
$$

\begin{tabular}{rr|r|r|r|r|r|}
5.0 & 0.4 & & 1.7 & 1.1 & 0.7 & 9.9 \\
\hline 95.0 & 99.6 & 100.0 & 98.3 & 98.9 & 99.3 & 90.1 \\
\hline \multicolumn{6}{c}{$(43.1) * * *$}
\end{tabular}

Comfort

$$
\begin{aligned}
& \text { Yes } \\
& \text { No }
\end{aligned}
$$

\begin{tabular}{rr|r|r|r|r|r|}
9.6 & 57.2 & 48.3 & 36.2 & 27.7 & 1.0 & 16.2 \\
\hline 90.4 & 42.8 & 51.7 & 63.8 & 72.3 & 99.0 & 83.8 \\
\hline \multicolumn{7}{c}{$(314.1)^{* * *}$}
\end{tabular}

Safety

Yes

\begin{tabular}{rr|r|r|r|r|r|}
2.1 & 21.8 & 6.9 & 12.1 & 8.5 & 0.7 & 2.7 \\
\hline 97.9 & 78.2 & 93.1 & 87.9 & 91.5 & 99.3 & 97.3 \\
\hline \multicolumn{7}{c|}{$(115.8)^{* * *}$}
\end{tabular}

Lifestyle

$$
\begin{gathered}
\text { Yes } \\
\text { No }
\end{gathered}
$$

\begin{tabular}{rr|r|r|r|r|r|}
28.1 & 8.8 & 6.9 & 5.2 & 12.8 & 10.3 & 41.4 \\
\hline 71.9 & 91.2 & 93.1 & 94.8 & 87.2 & 89.7 & 58.6 \\
\hline \multicolumn{6}{c|}{$(106.4) * * *$}
\end{tabular}

Lack of options

$\begin{array}{rrrrrrrr}\text { Yes } & 23.1 & 16.5 & 13.8 & 27.6 & 33.0 & 70.5 & 7.2 \\ \text { No } & 76.9 & 83.5 & 86.2 & 72.4 & 67.0 & 29.5 & 92.8\end{array}$

Source: Research data.

*** Significant at $0.1 \%$; * Significant at $1 \%$; 
A main reason for the low adoption of the public transport is the bad quality of its services (Table 4). The comfort and frequency present the lowest percentages of good and very good evaluations (percentages ranging between 4\% and 36\%). In turn, the distribution of bus stops in the city presents the highest percentages of good and very good, ranging between $35 \%$ and $66 \%$. Bus users are those who criticize more severely the quality of the services, especially the comfort ( $6 \%$ of good and very good evaluations), commute time $(10 \%)$, frequency (12\%) and information about timetables and itineraries of buses (21\%).

Table 4 - Percentage of very good and good evaluations for the public transport characteristics according to type of transport used in the commute (chi-square statistic between parentheses)

\begin{tabular}{|c|c|c|c|c|c|c|c|}
\hline & Walking & $\begin{array}{l}\text { Private } \\
\text { Vehicle }\end{array}$ & Ride & $\begin{array}{c}\text { Chartered } \\
\text { bus }\end{array}$ & Shuttle & Bus & $\begin{array}{c}\mathrm{Bi} \\
\text { cycle }\end{array}$ \\
\hline \multirow[t]{2}{*}{ Time } & 36.0 & 28.9 & 7.9 & 34.2 & 71.0 & 10.2 & 44.1 \\
\hline & \multicolumn{7}{|c|}{$(132.3) * * *$} \\
\hline \multirow[t]{2}{*}{ Comfort } & 20.7 & 13.3 & 10.5 & 5.3 & 36.2 & 5.6 & 13.6 \\
\hline & \multicolumn{7}{|c|}{$(47.3)^{* * *}$} \\
\hline \multirow[t]{2}{*}{ Frequency } & 18.7 & 10.8 & 5.3 & 34.2 & 11.6 & 11.9 & 13.6 \\
\hline & \multicolumn{7}{|c|}{$(25.4) * * *$} \\
\hline \multirow[t]{2}{*}{ Bus stop } & 50.0 & 38.6 & 52.6 & 39.5 & 34.8 & 48.6 & 66.1 \\
\hline & \multicolumn{7}{|c|}{$(11.9)+$} \\
\hline \multirow[t]{2}{*}{ Information } & 33.3 & 27.1 & 26.3 & 31.6 & 31.9 & 20.9 & 47.5 \\
\hline & \multicolumn{7}{|c|}{$(16.4)^{* *}$} \\
\hline
\end{tabular}

Source: Research data.

*** Significant at $0.1 \%$ ** Significant at $1 \%$;

The patterns of associations

We now analyze how the multiple characteristics previously presented are jointly associated with the transport mode. Firstly, we applied MCA to the whole set of nominal variables presented in Tables 2 and 3 in order to identify common dimensions of analysis. Secondly, we applied CA to the selected dimensions of the MCA in order to group the characteristics that are more strongly associated, identifying patterns of association between the characteristics under analysis.

We selected the three principal dimensions of the MCA with higher contributions to the total inertia, which explained $25 \%$ of the total variability of the chi-square statistic (total inertia). Based on the contribution of the categories of analysis to the inertia of each dimension, we interpreted these dimensions as follows: 
Dimension 1 - Private vehicle and comfort versus bus and lack of option

This dimension presents the largest contribution to the total inertia's variability $(11.5 \%)$. It strongly reflects the opposition between opting for a private vehicle or a public bus. On the negative side, the categories that contribute most to its total inertia are: the use of public transport (17\% of the total inertia), travel time greater than 40 minutes (14\%), and choice associated with the lack of option (10\%). On the positive side: choice associated with time $(8 \%)$, use associated with comfort $(6 \%)$, and use of private vehicle $(6 \%)$.

Dimension 2 - Active transport, health and lifestyle versus private vehicle and comfort

This is the dimension with the second largest contribution to the total inertia $(8.3 \%)$. It is strongly influenced by the dichotomy between active and motorized transport. On the positive side, the categories that contribute most to its total inertia are: choice related to health (11\%), choice for walking $(9 \%)$, bicycle $(8 \%)$ and choice associated with lifestyle $(8 \%)$. On the negative side, the most influential categories are: use of private vehicle (16\%) and choice related to comfort $(8 \%)$ and safety (4\%).

Dimension 3 - Intercampus shuttle and low income versus bicycle and health

This dimension explains $5.5 \%$ of the total inertial, being the third largest contribution, and it is largely influenced by the dichotomy between the use of intercampus shuttle by low income students and the use of bicycle due to health reasons. On the positive side, the categories that contribute most to its inertia are: the choice of intercampus shuttle (28\%), family income lower than $\mathrm{R} \$ 1,600$ (13\%), and bad health (8\%). On the negative side, the most influential categories are: use of bicycle (7\%), travel time between 21 and 40 minutes $(6 \%)$ and choice associated with health (5\%).

Figure 1 presents the coordinates of the categories of analysis plotted in the Euclidean space formed by the three dimensions of the MCA. The identification of the patterns of association is based on categories that are located in approximately the same direction from the origin and in approximately the same region of the space. To facilitate this identification, we applied CA to group categories with relatively homogeneous coordinates. Five groups of categories were defined, and the differences between the average values of these group explained $76.6 \%$ of the total variability of the distances between the categories in Euclidean space (semi-partial R2). The groups are represented by the same colors and symbols in Figure 1. 
Figure 1 -Coordinates of the categories of analysis in the dimensions of the MCA

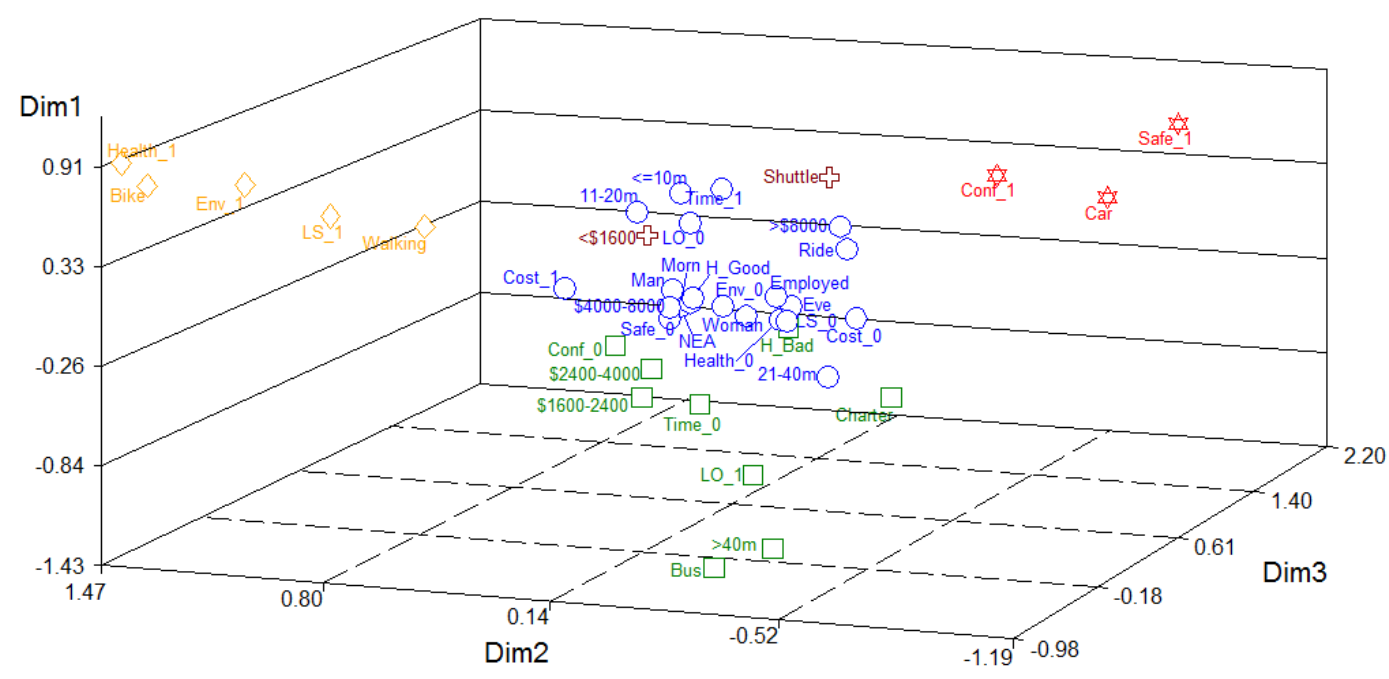

Source: Research data.

Groups of categories are defined by the same symbols and colors

Categories of income: $<=\mathrm{R} \$ 16000 ; \mathrm{R} \$ 16000-24000 ; \mathrm{R} \$ 24000-40000 ; \mathrm{R} \$ 40000$ 80000; >R \$80000. Period: Mon (Morning); Eve (Evening). Sex: Man; Woman. Economic status NEA (non-employed); Employed. Health Status: H_Good (very good, good); H_bad (regular, bad, very bad). Travel time: $<=10 \mathrm{~m}$ (up to $10 \overline{\mathrm{min}}$ ); $10-20 \mathrm{~m} ; 20-40 \mathrm{~m} ;>\overline{40} \mathrm{~m}$. Motive of choice is cost: Cost_1 (yes); Cost_0 (no). Motive is time: Time_1 (yes); Time_0 (no). Motive is health: Health_1 (yes); Health_0 (no). Motive is environment: Env_1 (yes); Env_0 (no). Motive is comfort: Comf_1 (yes); Comf_0 (no). Motive is safety: Safe_1 (yes); Safe_0 (no). Motive is lifestyle: LS_1 (yes); LS_0 (no). Motive is lack of option: LO_1 (yes); LO_O (no).

The groups highlight important patterns of association between the analytical categories. First, the strong association between the use of private vehicle (car), comfort (comf_1) and safety (safe_1). On the other side, the adoption of active modes (bike and walking) are mainly associated with health (heath_1), environmental (env_1) and lifestyle (LS_1) motivations. In other words, while the choice of active modes of transport is mainly driven by lifestyle and positive attitudes toward the environment and physical activity, the use of private vehicles is mainly driven by concerns in relation to comfort and safety.

As expected, the use of the intercampus shuttle (shuttle) is mainly associated with students with family income lower than $\mathrm{R} \$ 1,600(<\mathrm{R} \$ 1600)$, who are more likely to live in Moradia. In turn, the use of public transportation (bus) and charter buses (charter) 
is mainly associated with middle-low income ( $\mathrm{R} \$ 1600-2400$ and $\mathrm{R} \$ 2400-4000)$, bad health ( $\mathrm{H}_{-}$bad), and long commuting time $(>40 \mathrm{~m})$. In fact, the main reason to use these transport modes is the lack of option (LO_1). The reasons related to commuting time and comfort are rarely remembered by their users (association with the categories Time_0 and Comf_0).

Finally, we have a group associating the choice for rides (ride) and the remaining categories of analysis. In comparison to other transport modes, ride is relatively near to the centroid, so it makes a relatively small contribution to the chi-square statistic and contributes relatively little to the inertia of the three dimensions under analysis. In other words, the patterns of association of this transport mode and the other categories in this group are not as strong as those identified by the previous clusters.

\section{Discussion}

The population analyzed in this study provides important elements to understand the choices of mode of transport in metropolitan areas. Results cannot be merely generalized to the whole population, since interviewees represent highly educated young students, mainly from upper-middle classes, and these social groups are more likely to adopt active transport (RUIZ; BERNABÉ, 2014). Nonetheless, to a large extent their choices reproduce those observed for the whole population in the Campinas Metropolitan Area (CMA). Approximately a quarter uses private cars, a quarter walks and another quarter uses public buses. The use of bicycles is only slightly higher than that observed in the CMA (8\% vs. 2\%), despite efforts to implement bicycle lanes in the campus neighborhood.

Results largely reinforce previous analysis of the literature as to the motives of transport choice. High-income users tend to prefer private vehicles, mainly because they are safer and more comfortable. The household expenditures with private transportation in Brazil are five times higher than that with public transport, and are highly concentrated in the top tenth of the income distribution (CARVALHO; PEREIRA, 2012). Individuals who can afford a private vehicle feel safer using private motorized transport rather than using public or active transport (KAMARGIANNI et al., 2015; ŞIMŞEKOĞLU; NORDFJÆRN; RUNDMO, 2015). Traffic-related accidents and crime rates are high in Campinas, making people feel unsafe when walking in some areas or cycling on busy roads. In spite of huge traffic congestion in the rush hours, private transport will still be preferred if the comfort it provides is greater than other choices (ESPINO; DE DIOS ORTÚZAR; ROMÁN, 2007). Users evaluate the quality of the public transport in Campinas as being very bad and the weather conditions are not totally suitable for a wide adoption of active transport, since days are predominantly hot and rainy.

Public transport prevails among low-income users and the main motive of their choice is the lack of alternatives, above all due to budget constraints. These users would probably prefer a private vehicle if they could afford one. Public transport in Campinas is exclusively by bus, and the average commuting time is very high, more than an hour. Private vehicles are more versatile and faster, and this option is particularly favored by 
those who study and work. The time spent accessing the bus service and the final destination is e a weakness of the public transport system (KRYGSMAN; DIJST; ARENTZE, 2004; POLAT, 2012). But the spatial distribution of bus stops is not the main concern in this case. The low satisfaction with the quality of the public transport arises mainly from the lack of comfort, the inadequate frequency of the buses and the high total time spent on the trips.

Results also highlight the use of active transport among upper-middle classes. Distance is an important barrier to active commuting (RUIZ; BERNABÉ, 2014; WOODS; NELSON, 2014), and rents in the university neighborhood tend to be relatively higher than those in more distant locations. Those low-income students living in the university residence hall (Moradia) prefer the shuttle service, which is also offered free of charges. Besides the low cost, the main reasons for their choices are comfort and safety. In turn, the main reasons related to the choice of active modes of transport are the perceived benefits on health and positive attitudes toward the environment. These results largely reinforce previous analyses of the literature about the benefits of active transport on health (DE NAZELLE et al., 2011; JARRETT et al., 2012; ROJAS-RUEDA et al., 2012; SCHAUDER; FOLEY, 2015) and the important role of attitudes and perceptions on the choice of transport mode (GATERSLEBEN; APPLETON, 2007).

\section{Conclusion}

Results presented in this study do not represent causal relationships. In other words, we cannot definitively say that the choice of the mode of transport is caused by the characteristics under analysis. Nevertheless, the patterns of association observed in this study explain to a large extent the reasons why people prefer private vehicles rather than public or active modes of transport. Although we expected that a group of young well-educated persons would present more sustainable transport habits, their choices largely reflect those made by the whole population in the city. The use of active transport is very low, suggesting that structural factors are playing more important roles than personal characteristics in the peoples' choice for the mode of transport. Among these factors, the lack of public and traffic safety that curbs the adoption of active transportation and the poor quality of the public transport system should be underscored.

These results may suggest a wide spectrum of actions to stimulate sustainable transport. For example, the lack of safety recommends investments in the construction of appropriate infrastructure, such as exclusive lanes for buses and bicycles, modernization and better planning of the bus fleet, and improvements in public safety. A major challenge are the constraints imposed by limited local budgets and the lack of coordination among different institutional and governmental actions (Federal, State and Local). Although public transport is a local issue, it needs support from Federal and State governments, given the massive volume of financial resources needed to implement all these policies (MENEZES; MAIA; DE CARVALHO, 2017). Policies to stimulate the use of public and active transport can also have side effects on the public opinion in the short term. 
Campinas has almost one car per inhabitant, and actions to increase spaces for bicycles and buses on its congested roads will certainly bring a huge dissatisfaction among private car users.

A second main concern refers to people's attitudes and perceptions toward active transport (GATERSLEBEN; APPLETON, 2007). Investments in infrastructure may not necessarily meet the expected results if bicycling and walking habits do no become more positive. Currently, the use of the bicycle remains restricted to a small minority of people with positive attitudes and perceptions. Awareness campaigns can help, but changes in the habits of the population can take longer.

Finally, the study also presents a roadmap for future researches. In particular, the need for additional studies to understand how the recent proliferation of ride hailing and bike-share systems in Campinas may have affected attitudes, perceptions and, consequently, the peoples' choice for the mode of transport. Specially because some main motives influencing the choice for public and active transport, namely the lack of comfort and safety, seems to have remained with few or no changes. Further studies could also apply choice modelling to predict how changes in structural constraints, such as infrastructure and public safety, may affect individual's demand for the mode of transport.

\section{References}

ANDERBERG, M. Cluster analysis for applications. New York: Academic Press, 1973.

BEAUDOIN, J.; FARZIN, Y. H.; LIN LAWELL, C. Y. C. Public transit investment and sustainable transportation: A review of studies of transit's impact on traffic congestion and air quality. Research in Transportation Economics, v. 52, p. 15-22, 2015.

BEIRÃO, G.; SARSFIELD CABRAL, J. A. Understanding attitudes towards public transport and private car: A qualitative study. Transport Policy, v. 14, n. 6, p. 478-489, 2007.

BEN-AKIVA, M. E.; LERMAN, S. R. Discrete choice analysis: theory and application to travel demand. Cambridge, MA: MIT Press, 1985.

BERGSTAD, C. J. et al. Affective-symbolic and instrumental-independence psychological motives mediating effects of socio-demographic variables on daily car use. Journal of Transport Geography, v. 19, n. 1, p. 33-38, 2011.

BONNEL, P.; CHAUSSE, A. Urban travel: Competition and pricing. Transport Review, v. 20, n. 4, p. 385-401, 2000.

BÖSEHANS, G.; WALKER, I. 'Daily Drags' and 'Wannabe Walkers' - Identifying dissatisfied public transport users who might travel more actively and sustainably. Journal of Transport and Health, v. 3, n. 3, 2016.

BRESSON, G. et al. Economic and structural determinants of the demand for public transport: An analysis on a panel of French urban areas using shrinkage estimators. Transportation Rese- 
arch Part A: Policy and Practice, v. 38, n. 4, p. 269-285, 2004.

CARVAlHO, C. H.; PEREIRA, R. H. Gastos das Famílias Brasileiras com Transporte Público e Privado no Brasil: Uma Análise da POF 2003 e 2009. Texto para Discussão - IPEA, n. 1803, p. $1-30,2012$.

CATS, O.; LOUTOS, G. Real-time bus arrival information system: An empirical evaluation. Journal of Intelligent Transportation Systems, v. 20, n. 2, p. 138-151, 2016.

COCHRAN, W. G. Sampling techniques. New York: Wiley, 1977.

DE NAZELLE, A. et al. Improving health through policies that promote active travel: A review of evidence to support integrated health impact assessment. Environment International, v. 37, n. 4, p. 766-777, 2011.

DE VASCONCELLOS, E. A. Urban change, mobility and transport in São Paulo: Three decades, three cities. Transport Policy, v. 12, n. 2, p. 91-104, 2005.

DENATRAN. Frota de veículos. Disponível em: <http://www.denatran.gov.br/index.php/ estatistica/237-frota-veiculos>. Access in: 9 nov. 2016.

ESPINO, R.; DE DIOS ORTÚZAR, J.; ROMÁN, C. Understanding suburban travel demand: Flexible modelling with revealed and stated choice data. Transportation Research Part A: Policy and Practice, v. 41, n. 10, p. 899-912, 2007.

FDA. National Household Travel Survey. Disponível em: < http://nhts.ornl.gov/documentation. shtml>. Access in: 1 jan. 2014.

GATERSLEBEN, B.; APPLETON, K. M. Contemplating cycling to work: Attitudes and perceptions in different stages of change. Transportation Research Part A: Policy and Practice, v. 41, n. 4, p. 302-312, 2007.

GREENACRE, M. Correspondence analysis in practice. Boca Raton, Fla.; London: Chapman \& Hall/CRC, 2007.

HARTIGAN, J. A. Clustering Algorithms. New York: John Wiley \& Sons, 1975.

HOFFMAN, D. L.; FRANKE, G. R. Correspondence analysis: graphical representation of categorical data in marketing research. Journal of Marketing Research, v. XXIII, n. Aug, p. 213-227, 1986.

IEA. Energy technology perspective. Scenario and strategies to 2050. Paris: OECD/IEA, 2008.

IPEA. IPEADATA. Disponível em: <http://ipeadata.gov.br/>. Acesso em: 15 nov. 2016.

JAIN, S. et al. Identifying public preferences using multi-criteria decision making for assessing the shift of urban commuters from private to public transport: A case study of Delhi. Transportation Research Part F: Traffic Psychology and Behaviour, v. 24, p. 60-70, 2014. 
JARRETT, J. et al. Effect of increasing active travel in urban England and Wales on costs to the National Health Service. The Lancet, v. 379, n. 9832, p. 2198-2205, 2012.

KAMARGIANNI, M. et al. Investigating the subjective and objective factors influencing teenagers' school travel mode choice - An integrated choice and latent variable model. Transportation Research Part A: Policy and Practice, v. 78, p. 473-488, 2015.

KENNEDY, C. A. comparison of the sustainability of public and private transportation systems: Study of the Greater Toronto Area. Transportation, v. 29, n. 4, p. 459-493, 2002.

KRYGSMAN, S.; DIJST, M.; ARENTZE, T. Multimodal public transport: An analysis of travel time elements and the interconnectivity ratio. Transport Policy, v. 11, n. 3, p. 265-275, 2004.

LOIS, D.; LÓPEZ-SÁEZ, M. The relationship between instrumental, symbolic and affective factors as predictors of car use: A structural equation modeling approach. Transportation Research Part A: Policy and Practice, v. 43, n. 9-10, p. 790-799, 2009.

MA, L.; DILL, J. Associations between the objective and perceived built environment and bicycling for transportation. Journal of Transport and Health, v. 2, p. 248-255, 2015.

MCTI. Estimativas anuais de emissões de gases de efeito estufa no Brasil. Brasília: [s.n.].

MENEZES, E.; MAIA, A. G.; DE CARVALHO, C. S. Effectiveness of low-carbon development strategies: Evaluation of policy scenarios for the urban transport sector in a Brazilian megacity. Technological Forecasting and Social Change, v. 114, p. 226-241, jan. 2017.

MULLEY, C. et al. Public transport and health: Publicising the evidence. Journal of Transport and Health, v. 3, n. 2, p. 131-132, 2016.

PARKIN, J.; WARDMAN, M.; PAGE, M. Estimation of the determinants of bicycle mode share for the journey to work using census data. Transportation, v. 35, n. 1, p. 93-109, 2008.

PAULLEY, N. et al. The demand for public transport: The effects of fares, quality of service, income and car ownership. Transport Policy, v. 13, n. 4, p. 295-306, 2006.

POLAT, C. The demand determinants for urban public transport services: a review of the literature. Journal of Applied Sciences, v. 12, n. 12, p. 1211-1231, 2012.

PUCHER, J. et al. Walking and Cycling to Health: A Comparative Analysis of City, State, and International Data. American Journal of Public Health, v. 100, n. 10, p. 1986-1992, out. 2010.

REDMAN, L. et al. Quality attributes of public transport that attract car users: A research review. Transport Policy, v. 25, p. 119-127, 2013.

ROJAS-RUEDA, D. et al. Replacing car trips by increasing bike and public transport in the greater Barcelona metropolitan area: A health impact assessment study. Environment International, v. 49, n. 15, p. 100-109, 2012. 
RUIZ, T.; BERNABÉ, J. C. Measuring factors influencing valuation of nonmotorized improvement measures. Transportation Research Part A: Policy and Practice, v. 67, p. 195-211, 2014.

SAELENS, B. E. et al. Relation between higher physical activity and public transit use. American Journal of Public Health, v. 104, n. 5, p. 854-859, 2014.

SCHAUDER, S. A.; FOLEY, M. C. The relationship between active transportation and health. Journal of Transport and Health, v. 2, n. 3, p. 343-349, 2015.

SENER, I. N.; LEE, R. J.; ELGART, Z. Potential health implications and health cost reductions of transit-induced physical activity. Journal of Transport and Health, v. 3, n. 2, p. 133-140, 2016.

ŞIMŞEKOĞLU, Ö.; NORDFJÆRN, T.; RUNDMO, T. Predictors of car use habit strength in an urban Norwegian public. Transportation, v. 42, p. 1-14, 2015.

STM. Pesquisa Origem e Destino 2011 - Região Metropolitana de Campinas. [s.l: s.n.].

UNECE. 2015 Inland Transport Statistics. New York and Geneva: [s.n.].

WOODS, C. B.; NELSON, N. M. An evaluation of distance estimation accuracy and its relationship to transport mode for the home-to-school journey by adolescents. Journal of Transport and Health, v. 1, p. 274-278, 2014.

WOOLDRIDGE, J. M. Introductory Econometrics: A Modern Approach. 2. ed. Mason: Thomson South-Western, 2003.

YANG, Y. A dynamic framework on travel mode choice focusing on utilitarian walking based on the integration of current knowledge. Journal of Transport and Health, v. 3, p. 336-345, 2016. 
Alexandre Gori Maia

■gori@unicamp.br

ORCiD: https://orcid.org/0000-0003-0075-5094
Submitted on: 09/09/2017

Accepted on: 15/05/2020

2020;23:e01884

\section{Cristiane Silva de Carvalho}

$\square$ cristiane.carvalho@cequa.cl

ORCiD: https://orcid.org/0000-0002-9493-7667

\section{Leonardo César Venâncio}

๑ leozinhowe8@hotmail.com

\section{Eduardo Dias Dini}

$\square$ eduardodiasdini@gmail.com

How to cite: MAIA, A. G.; CARVALHO, C. S.; VENANCIO, L. C.; DINI, E. D. The motives behind transport mode choice: a study with university students in Brazil. Ambiente \& Sociedade. São Paulo, v. 23, p. 1-20, 2020. 


\title{
Os motivos da escolha pelo modo de transporte: um estudo com estudantes universitários no Brasil
}

\author{
Alexandre Gori Maia \\ Cristiane Silva de Carvalho \\ Leonardo César Venâncio \\ Eduardo Dias Dini
}

São Paulo. Vol. 23, 2020

Artigo Original
Resumo: Analisamos os principais motivos da adoção dos meios de transporte (privado, público, bicicleta, caminhada e outros) entre estudantes universitários de Campinas. As análises baseiam-se em dados primários coletados de 1.179 estudantes por meio de entrevistas online e pessoais no segundo semestre de 2014. A análise de correspondência múltipla e a análise de cluster são usadas para identificar grupos comuns de escolhas. $O$ transporte público prevalece entre os usuários de baixa renda, e a principal razão para sua escolha é a falta de alternativas. Aqueles que podem financiar custos mais elevados preferem um veículo privado, mais seguro e confortável. Por sua vez, a adoção do transporte ativo permanece restrita a um pequeno grupo de usuários com atitudes positivas em relação à saúde e ao meio ambiente. $\mathrm{O}$ estudo finalmente discute as implicações de fatores estruturais, como infraestrutura e segurança pública, em políticas públicas voltadas para um sistema de transporte urbano sustentável.

Palavras-chave: Transporte ativo; bicicleta; transporte público urbano; caminhada; análise multivariada;

Como citar: MAIA, A. G.; CARVALHO, C. S.; VENANCIO, L. C.; DINI, E. D.. The motives behind transport mode choice: a study with university students in Brazil. Ambiente \& Sociedade. São Paulo, v. 23, p. $1-20,2020$. 


\title{
Los criterios para selección del modo de transporte: un estudio con estudiantes universitarios de Brasil
}

\author{
Alexandre Gori Maia \\ Cristiane Silva de Carvalho \\ Leonardo César Venâncio \\ Eduardo Dias Dini
}

São Paulo. Vol. 23, 2020

Artículo original
Resumen: Analizamos las principales razones de la adopción de los modos de transporte (privado, público, bicicleta, caminata y otros) entre estudiantes universitarios de Campinas. Los análisis se basan en datos primarios recopilados de 1,179 estudiantes a través de entrevistas en línea y personales en la segunda mitad de 2014. El Análisis de Correspondencia Múltiple y Análisis de Cluster son usados para identificar grupos de elección comunes. El transporte público prevalece entre los usuarios de bajos ingresos debido a la falta de alternativas. Los estudiantes que pueden pagar más prefieren un vehículo privado, considerados más seguros y cómodos. La adopción de modos de transporte activos permanece restringida a un pequeño grupo de usuarios con actitudes positivas hacia la salud y el medio ambiente. El estudio finalmente discute las implicaciones de las restricciones estructurales, como la infraestructura y la seguridad pública, sobre las políticas públicas dirigidas a un sistema de transporte urbano sostenible.

Palabras-clave: Transporte activo; bicicleta; transporte público urbano; caminando; análisis multivariable;

Como citar: MAIA, A. G.; CARVALHO, C. S.; VENANCIO, L. C.; DINI, E. D.. The motives behind transport mode choice: a study with university students in Brazil. Ambiente \& Sociedade. São Paulo, v. 23, p. $1-20,2020$. 